Making visible the 'space of betweenness': Understanding women's limited access to leadership in regional Australia

*Alison Sheridan, University of New England

Fiona Haslam McKenzie, Curtin University of Technology

Leonie Still, University of Western Australia

*Corresponding author:

Professor Alison Sheridan

School of Business, Economics and Public Policy

Faculty of The Professions

University of New England

Armidale NSW 2351

AUSTRALIA

email: asherida@une.edu.au

Tel: +61 0267732367

Fax: +61 0267733148 


\title{
Making visible the 'space of betweenness': Understanding women's limited access to leadership in regional Australia
}

\author{
Abstract \\ In this paper we proffer the metaphor of a 'space of betweenness' to explain \\ women’s limited access to leadership roles in Australian peak industry and \\ regional governance boards. In reviewing the statistics around women's \\ leadership roles in regional Australia, and women’s own stories of their \\ activities, we argue that despite women's contribution to their local communities \\ through their diverse roles in paid work, it seems the triple jeopardy of their sex, \\ their location and the nature of their businesses positions them in a 'space of \\ betweenness', rendering them invisible and limiting their ability to access many \\ formal leadership roles.
}

Keywords: Regional; leadership; women; business; governance

\section{Introduction}

Women's limited representation in leadership positions in Australia continues to attract attention, both in the popular press and in public policy circles. Despite more than 35 years of significant changes to women's participation rates in the paid workforce, they continue to be poorly represented in formal leadership positions across all industry sectors. While much of the research into women's leadership roles has focused on the corporate sector (Still, 2004) and the public sector (Office of the Director of Equal Opportunity in Public Employment 1998; Rindfleish and Sheridan 2003), in recent years 
there has been a growing interest in women's experience of leadership in rural industries (Alston 1998a; Liepins 1998; Haslam McKenzie 1999; Alston 2000; Pini et al. 2003; Pini 2005a). A common theme across these Australian studies is the gendered nature of organizational practices and leadership (Alston 1998a; Liepins 1998; Pini et al. 2004; Sinclair 2005), reflecting similar findings internationally (Martin 1996; Wajcman 1999; Fenstermaker and West 2002; Powell and Graves 2003).

The shift in focus from women's leadership in the corporate sector, where much of the research done by scholars in business schools leaves the hegemony of capitalism largely unquestioned, to the rural spaces has allowed for richer analyses, inflected by the work of rural sociologists and feminist geographers who have questioned the dominance of the capitalist economy and made a space for recognising a diverse economy (GibsonGraham 2006).

This paper aims to make visible the varied roles those women who are located outside the farm gate, but not in urban areas, have taken on and to reflect on the reasons for their relative invisibility in formal leadership positions. It seems that despite women's contribution to their local communities through their diverse roles in paid and unpaid work and/or their businesses, formal leadership as captured in representation on boards in regional Australia, continues to reinforce the 'naturalness' of men in positions of authority and women in subordinate positions. We explore the doing of gender in regional Australia through our (co-opted) use of the notion of 'space of betweenness'. From this analysis we conclude that the discursive positioning of regional women in this ‘space of betweenness’ renders them invisible as candidates for leadership roles in Australian peak agricultural industry and regional governance boards. 


\section{Definitional and conceptual clarity}

To ensure definitional and conceptual clarity, there are a number of terms we employ throughout the paper that need to be explained within an Australian context. As we reviewed the literature surrounding women's roles in agriculture and in regional communities we recognized there was some slippage in the language around 'rural' and 'regional'. There is inconsistency in the descriptors for the sub-groups of the population who live outside the capital cities in Australia. Terms such as metropolitan/nonmetropolitan, urban, rural, regional and remote are often not defined, or have been defined differently in different classifications. Consequently, confusion can easily arise unless it is it is made clear which classification is being used in each instance (Haslam McKenzie and Lord 2002).

Australia is one of the least densely populated nations of the world; outside of the metropolitan areas, on average there are only 0.8 persons per square kilometre, although within these areas there is great variation. The Australian Bureau of Statistics (ABS) has developed a spatial categorisation system to capture the differences between regions in terms of physical remoteness from goods and services and opportunities for social interaction. ${ }^{1}$ In the ABS's Remoteness Structure, there are five broad classes of remoteness in Australia: Major Cities; Inner Regional; Outer Regional; Remote Australia; and Very Remote (Bureau of Transport and Regional Economics 2006). Approximately two-thirds (66.3\%) of the total population reside in Major Cities, while the rest are mainly residents of Inner and Outer Regional areas (31.1\%), with only 2.6\% of people in either Remote or Very Remote areas. 
The focus of our research is on women's activities in regional and remote Australia as defined by the spatial categorization used by the ABS. As such in this paper, we use the term regional to apply to those spaces outside of major cities and rurality is assumed to be a space where activities to do with agriculture and agricultural production are conducted. $^{2}$

The term 'leadership' in this paper refers to senior management and board governance positions with the opportunity to influence key decision making. In the rural and regional spheres these include agricultural commodity councils, rural industry research and development corporations, rural representative bodies, a sample of publicly listed agricultural companies, and government and/or semi-government bodies such as area consultative committees (ACCs) regional development boards (RDBs) and catchment management authorities (CMAs), all of which have been identified by policy makers as capturing important leadership roles in regional communities (Department of Transport and Regional Services 2005). The focus on board positions as a proxy for leadership is, of course, contentious. While we recognise that leadership can be manifested in many informal roles (Sinclair 2005), we engage with it here through board representation as it is a metric that is being employed by relevant policy makers.

\section{The 'space of betweenness'}

The framework we have developed in this paper to explore women's relative absence from formal leadership positions in regional Australia is based on our appropriation of the term 'space of betweenness'. While we are aware this term was employed by feminist geographers and ethnographers in the 1980s and 1990s as they were making sense of 
their role as researchers in the field, we saw an application to our current work with women in regional business. It seemed to us that the business women we were encountering were working in a variety of roles, operating in 'spaces of betweenness' and, as the feminist geographers described from their own experiences, often shifting between a position of 'insider status' meaning that they have first-hand experience and 'outsider status’ where they observe but do not or cannot participate (McDowell 1992; Katz 1994; Staeheli 1994; Nast 1994) in particular roles, depending upon political contexts and time.

Staeheli (2003) used the term 'space of betweeness' (sic) in a slightly different manner to capture what she perceived as the contested notion of community; in particular, highlighting how community links the 'private and the public in ways that reflect ideologies about responsibility for social welfare' (Staeheli 2003, 818). Her focus was on the shifting boundaries between the public and the private, as she argued that 'it is in the spaces between public and private that ideas about care and social justice are enacted' (Staeheli 2003, 817) but it is this sphere that the economic literature connotes as being local and therefore confined and constrained (Gibson-Graham 2002). While Midgely (2006) adapted the term ‘space of betweeness' (sic) to describe women’s economic involvement in their communities more generally, through their linking of the private and the public, we argue the term has an even greater significance for employed (including self-employed) women in regional communities. For these women, there are multiple dimensions to their location in a 'space of betweenness'; they are not only women, and so in the pervading ideology of western market economies often constructed as 'non-economic' (Midgley 2006; Cameron and Gibson-Graham 2003), they are often 
involved in (service) roles linking the private and public (Staeheli 2003) and they are also in the (physical) space between the city and the farm gate. This combination renders much of their activity invisible and, as we argue, can go some way to explaining women's continued poor representation in visible leadership roles in their regions and beyond.

Feminist scholars have developed an extensive body of work clearly demonstrating that women's work has historically been omitted in the construction of the 'economy'. Many feminists critique mainstream economic analysis as being 'masculinist' (Duerst-Lahti and Kelly 1995), non-reflexively presenting the economy from men's experience, and defining the typical economic actor as 'rational economic man' (Calas and Smircich 1992). In the rural spaces, Trauger (2004) reports how women farmers are 'out of place' because they are women. Feminist geographers have extended this critique to political geography to challenge the 'masculinism' inherent in political processes, where they describe it as 'associated with the illusion of transparent space and an allseeing vision' (Staeheli and Kofman 2004, 4).

Liepins (2000, 338) observed that public spaces in the community were rarely neutral physical places but that 'the practices of 'community' were negotiated through spatially separated and gendered relations'. The effect of these pervasive ideologies and practices has been to ignore the importance of gender and the myriad ways in which power relationships influence the macro structures. As Staeheli and Kofman $(2004,4)$ note, there is a propensity to focus on elite actors who either enjoy institutional power through their roles within the state or have the power 'to influence the state through nonstate institutions such as firms or nongovernmental organizations; the agents who wield 
such power are typically men'. As such, the standpoint of men dominates the public sphere. Women are excluded from 'not only economic power, but also knowledge and legitimacy’ (Trauger 2004, 296). This has implications for who assumes entitlement to, and who is assumed by others to be entitled to be in, the public sphere as 'leaders'.

The second dimension to our use of the metaphor of the 'space of betweenness' to explain women's relative absence from regional boards and organizations of influence extends the gender dimension to encompass the gendering of specific economic activities. Those economic activities dominated by men through ownership and employment enjoy a status not shared by those activities in which women predominate. The traditional division of labour between men as 'doers' and women as 'carers' are replicated in the labour market and the relative status afforded those activities (Edwards and Wajcman 2005; Glover and Kirton 2006) and reflect the division of labour across the public and private spheres (McDowell 2004).

The gendered nature of livelihood strategies is well established (Oberhauser et al. 2004). Feminists have provided persuasive evidence as to the ways in which care work is 'devalued as the feminized, private work of home, rather than as society’s work' (Lawson 2007, 2) and that '(women’s) caring skills are often given less value than (male) physical strength' (Glover and Kirton 2006, 49). The occupations and industries in which women tend to be found - the growing services sector - have been overlooked by economic policy makers. In their location in many roles that span the private and the public, women's employment is often not visible as ‘economic' activity and so we see labour markets continuing 'to function as mechanisms of systemic discrimination' (Lovering, 2001, 352). This dimension takes on even greater significance when seen in the context 
of public policy making designed to remove services in regional communities that were previously provided by government (Cheshire 2006). This points to the importance of heeding Pike et al's (2007) call for the questioning of who benefits from local and regional development. Such questioning can shine a light on how the distribution of power and resources within a community perpetuate social and economic inequality. While the fluidity of the boundaries between the public and private may have changed through public policy shifts, and there has been a stretching of our understanding of the changing spatialities of household, family and home, many of the gendered assumptions about who should do the caring, and what value is placed on it, remain uncontested, and the inequalities continue.

The final dimension to the 'space of betweenness' relates to the privileging of the urban over the rural and, we argue, the urban and rural over the regional. While unstated, most research into women's employment status focuses on urban women. The hegemony of the urban workforce is reinforced by the failure of researchers to even state that their work is based in an urban environment; the urban is the given. Australian researchers writing about the status of rural women stress the importance of distinguishing the context in which different groups of women operate; that the rural context needs to be seen as distinct from the urban context (Alston 1998b; Alston 2000; Fincher and Panelli 2001; Haslam McKenzie and Lord 2002; Pini 2003). In particular, it is argued that the tenacity of the traditional expectations of the 'supportive' farming woman and the determined, strong-willed man of the land (Pini 2005a), suggests that women aspiring to formal leadership in agricultural organizations may be facing even more constraints than their city counterparts. While we value the work differentiating the rural and metropolitan 
spaces, we believe this binary has rendered the women who do not fit into either of those categories unseen. Women's locations in spaces outside of the urban lead to different place-based opportunities and constraints and these differences need to be teased out.

\section{Methodology}

In the remainder of this paper we draw together findings from four projects examining women's business activity and leadership in regional contexts to demonstrate how the figurative device of the 'space of betweenness' has been a useful sensemaking tool. While each project was conducted independently of the others, we could see that together they told an interesting story about women's relative absence from formal leadership positions.

The first project explored women's experiences as small business owners in a regional community (Conway and Sheridan 2005). The second was a review of women's representation in key roles in a range of regional bodies in Australia (Haslam McKenzie et al. 2005). The third research project evaluated the efficacy of government strategies to increase the number of women in key decision making roles (Sheridan et al. 2008). The fourth project (Sheridan and Haslam McKenzie 2009) focused on updating the Missed Opportunities report (Elix and Lambert 1998) and tracking women’s representation in leadership positions in regional bodies of influence over the past decade.

In each of these projects we drew on the relevant descriptive statistics that were publicly available detailing women's economic activities, and in the first, third and fourth studies, we also conducted interviews. Drawing on these sources, in this paper we reflect on how women (and men) define and justify their activities, and in so doing discursively 
construct themselves and their location within that space. These stories help to make visible the norms and rules operating in regional communities, and how some discourses dominate over others (Eveline 1998). Through our cumulative reading of these studies, we recognised the aptness of the 'space of betweenness' lens for making sense of women's continued absence from formal leadership roles in regional contexts.

\section{Women's work in regional Australia}

While women are an integral part of the fabric of life in rural and regional Australia it has been well documented that their contribution was neither appreciated or understood until a flurry of academic (Fisher and Hutchison 1998; Franklin et al. 1994; Haslam McKenzie 1998; Alston 2000) and to some extent, political activity (Alston 1995; Alston 1996; Haslam McKenzie 1999) occurred in the last decade of the twentieth century highlighting women's contributions. For a time in the 1990s, there was an expectation amongst rural and regional women that their work and presence in family businesses, their communities and industries would begin to be recognised, valued and perhaps even celebrated.

At the community and local level there has been some recognition of women's public participation in community roles such as local government (Pini 2005c), and through their involvement in community groups such as the Country Women's Association (Teather 1995) and local sporting associations. While women's economic and social contribution to the agricultural industries was documented by Elix and Lambert (1998) in their report, Missed Opportunities - harnessing the potential of women in Australian agriculture, women living in regional locations are not only employed in agricultural industries. Teasing out the diversity of women's employment 
and geographical experiences in Australia by industry, we see in Table 1 that even in regional areas where agricultural industries have historically been dominant, women in agriculture make up only 15\% of employed women (Department of Transport and Regional Services 2005b) compared to $24.3 \%$ in good producing industries and $75.7 \%$ in service industries.

Insert Table 1 here

Research consistently shows women feel a general atmosphere of exclusion regarding formal leadership within non-metropolitan industry groups and achieve leading roles against the odds (Haslam McKenzie 1999; Wilkinson and Alston 1999; Pini 2003).

Fincher and Panelli $(2001,139)$ in describing the evolution of the Australian lobby group, Women in Agriculture, explain how the group presented 'rurality as a series of on- and off-farm sites in which male experience was privileged and valued, and women’s contributions were represented as insignificant and secondary’.

The globalisation of trade and economic activity is increasingly testing the ability of small communities and larger regions alike to adapt and achieve a competitive edge while also remaining liveable. At the same time, de-regulation and technology have impacted on women in regional and remote locations as they travel further to access goods and services such as banks and schools due to rationalizations and local closures. While the absence of these crucial local services has a significant impact on a community, many women have found innovative ways to fill these gaps through establishing their own businesses (Houghton and Strong 2004; Conway and Sheridan 
2005), which are often home based. As important as these enterprises are to the local community and individuals, the contemporary idea of the 'economy' excludes their contribution because they are forms of social production that support and sustain capitalist economic production but do not necessarily contribute to capital accumulation (see Gibson-Graham 1996; 2006).

Over the past two decades, in line with neoliberal public policy principles, Australian Commonwealth government regional development policies have been basically short-term and strongly oriented to self-determination and self-sufficiency. The strong message from the government is that the way ahead is one of self reliance, and 'the bush has to learn to find the solutions for itself' (Coghill 1997, 91), despite there being a growing body of research critiquing this notion of self-help as 'a panacea for rural decline’ (Cheshire 2006, 19).

While local communities have been encouraged to identify their own opportunities for growth and sustainability, they struggle to have control of the development process. Federal government policies have adopted the 'discourse of deregulation' and the 'rhetoric of regionalism' with light funding allocations (Beer 2000). There has been a drawing back of government intervention and the promotion of market solutions, which overlook the environmental and social costs.

An interesting dimension to the fluidity of what constitutes public and private spheres and women's spanning of these shifting boundaries, can be seen in the shift to more 'local solutions' for regional problems, at the same time as there were concerted efforts by government at both the federal and state levels in Australia to increase women's representation in government and semi-government boards. The Federal 
government, through the Office of Women and its policy AppointWomen, undertook a number of initiatives to increase women's representation on government boards, with similar programs enacted at the state level. Despite these efforts little had changed with respect to women's representation in formal leadership roles within agricultural organisations or within regional organisations more generally.

\section{Women's entrée to leadership in regional Australia}

Implicit in many formal leadership roles in regional Australia are the assumptions that business experience is necessary to be a leader (Alston 2000), and that the reason for women's poor representation in these roles is their lack of such experience (Alston 1998c). Such assumptions clearly warrant challenging when we look more closely at women's employment profiles and business experiences in regional Australia.

As can be seen in Table 2, women are represented across a range of occupational groups in regional Australia, with more than $25 \%$ of employed women in regional and remote Australia found in the management and professional categories, the occupations often drawn from for formal leadership roles (Sheridan and Milgate 2005), apparently making them well qualified to hold key leadership positions according to current expectations. This represents a significant shift in their occupational representation of thirty years ago (Houghton and Strong 2004).

Insert Table 2 here 
With respect to their role as small business owners, Houghton and Strong (2004) provide one of the few studies into women's business in regional and remote Australia. Through a national survey, interviews and focus groups, they found that the businesses owned and managed by women had a significant impact on their local economies, in terms of both employment and incomes, and extended the breadth of a region's business mix. For women in many communities, these businesses provided a strategic vehicle for diversifying the income sources, and provided a greater variety of end users for locally grown commodities (Houghton and Strong 2004), which can be argued to be a key contributor to regional development. Similar findings were reported by Oberhauser and Pratt (2004) in their work in South Africa where they found women's collaborative economic activities were not only beneficial for their individual well-being, but also created positive outcomes for the economic and social well-being of their communities. Martin, Hanson and Fontaine (2007) also highlight the role women's businesses played in changing their communities. The flow-on effects of women-owned businesses was evident in a recent study in a regional community in Australia (Conway and Sheridan 2005), with all participants reporting they employed local business services to support their businesses.

Internationally, women have been identified as a largely untapped pool of entrepreneurial talent (OECD 2003). It seems that one of the reasons for them being 'untapped' in regional economies is their limited visibility. Between the farm gate and the city, little attention has been focused on women's contributions to their local economies. That women's economic activities do not replicate the traditional businesses in regional locations - that is primary production - but are primarily service oriented, may be a 
contributing factor to their oversight. The close association of hegemonic masculinity with production and management in western economies is well established (Connell and Wood 2005). In the neo-liberalist discourse pervading regional development (Shortall 2002), and the masculinist discourse surrounding regional development (Pini 2006), women's businesses, with their service orientation, linking as they often do the public and the private, are not recognised as 'real' businesses. This is highlighted by the comment of a male member of a regional development body interviewed (Sheridan et al. 2008). He unreflexively reinforced the stereotypes inherent in the masculinist discourse of business when he noted:

I mean they [women] are more into health services whereas I, as a bloke, am probably more about thinking of economic development; of what new industry.....

His association of women with health services and men with economic development reinforces a common dichotomy between women's and men's work, which works to the disadvantage of women's business activities, because unlike male business owners in their communities, women continue to be constructed as 'non-economic'. This discursive regime renders them invisible, 'locked in the subordinate, under/devalued position vis a vis the 'core' economy' (Cameron and Gibson-Graham 2003, 151). As with the exclusion of female entrepreneurs from formal and informal networking in the UK that Carter (2000) describes, the consequences of this invisibility are profound. For instance, most of the networking support provided by regional development agencies in the United Kingdom has been directed to manufacturing businesses, rather than to the service sector where women's businesses are likely to be found (Rees 2000). Similar patterns are evident in Australia, where Grant and Rainnie (2005) found that regional development 
grants were less likely to be allocated to industries in which women dominated (for example, retail, community services, health and education), than for those in which men were traditionally found (agriculture and manufacturing).

In their discussion of the gendered dimensions to innovation, Blake and Hanson (2005) challenge the common assumption by policy makers that innovation equates to 'technical innovation', and so precludes service oriented innovation. This privileges the areas in which men dominate in terms of ownership and employment. This is not only representative of how innovation is valued, but is relevant to which businesses more generally are recognised as 'significant' in regional areas, and so visible to policy makers. Lovering (2001) critiques the prevailing assumption that regional business is significant if it is an exporting business. As he notes, most people earn their income through serving the needs of their neighbours in some way. He further argues that 'the scenario of 'local production for local needs', especially at the regional ... scale, deserves to be rescued from its almost total academic neglect' (Lovering 2001, 351). In failing to value women’s businesses, policy makers are not recognising how these businesses may be enhancing the wider development of the region (Rees 2000).

Examples of women's businesses not being seen as 'important', and therefore less likely to be 'noticed', were provided by the women participating in focus groups held to explore women's experiences as business owners in a regional community (Conway and Sheridan 2005). The participants spoke of their efforts to become part of the local business groups. A consistent theme to emerge from the focus groups was that that these businesses, focused as they are 'on serving the needs of their neighbours' (Lovering 
2001, 351), and often owned by women, were perceived by the women as not to be valued or recognised by local business groups.

A woman who owned a professional services business (which has been nationally recognised though industry awards) cited the local credit union as a positive example of where she was taken seriously, unlike her experience with other financial institutions, which clearly infuriated her.

I think the reason I like the Credit Union ... is because they took me seriously in business. I don't often think of myself as a woman in business, I think of myself as being in business and making it work. I think of the people, my staff, the people I'm creating a livelihood for. I feel a great responsibility for their financial welfare at the point when they work for me. When I think of being treated as a woman in business, it has been financial institutions; they have wanted to talk to my husband or wanted his signature. And he knows stuff all about my business. And thank you that's how it shall remain because that's how it works.

From earlier research on women in small businesses in a regional community there are many instances of women's businesses developing in response to a perceived gap in their communities. One woman described how her private nursing service had developed over a 17 year period, now employing 44 staff. As she noted, the 'bulk of our work has become the government purchasing services from us'; services which were previously provided through the community health system but which were now outsourced.

In describing her motivation for establishing her business, she almost apologetically described it as: 
ideological, at the beginning and it still is ... I still have this vision that you can actually have all the ideals that you once had when you wanted to be a nurse and put that into practice, and really put your money where your mouth was, in terms of ideals, in what you thought. So I decided how you could still maintain those ideals. It sounds a little corny now bit at the time it was more like putting love into action.

In this narrative, the shifting boundaries between the public and the private create a tension for the woman. Her business was based on the provision of caring services, and she wanted to do this in a manner that was consistent with her personal values. In framing her comments as 'a little corny' it was as though she felt her motivation wasn't as legitimate as others. This was reinforced through her description of how the business developed when she recounted that:

The biggest loan I got at the beginning was $\$ 500$ which was used for three fax machines and the answering machine. I sort of did everything by hand. I think if I had been a clever business woman I could have done a lot better than I have done.

Given that she had been in business for 17 years and was one of the most significant employers in the town, her apparent sense of not being 'clever' may be reflective of the difficulties women face in having their business recognised. In some ways she replicated this discounting of her own business in describing the men who also let space in the building in which her business was based. While she spoke of them as being very supportive of her, she noted that 'their businesses were so different from mine - they were importing stuff' (italics added by authors). These businesses were not, however, employing nearly the number of staff her business was, and yet she saw their businesses 
as in some ways more 'serious' than hers. Further, she described how others didn't take her business 'seriously', so she had to draw on the men she shared the building with to have to 'speak on my behalf'.

Another of the women had run a training company for the past decade, from which she recounted great satisfaction in seeing that the 'graduates' of her programs could be employed in the town.

I guess I am in the type of businesses where I don't think you are going to make instant money, it’s just not that type of business. So long as I can get there, have a wage, and feel I am doing good. I guess the satisfaction of knowing that most people who do the courses get jobs, and that people who do something with me are successful. So there are those types of brownie points.

These women's stories shed light on the 'space of betweenness' these local business women are located in their communities. The slippery boundaries of what is seen as 'real' business in these communities helps to provide a basis for understanding their limited access to more formal leadership roles.

\section{Women's representation in formal regional leadership roles}

In a recent review of women in regional and rural Australia, the Department of Transport and Regional Services (DoTARS) provided a snapshot of women's representation in key roles in a range of regional and rural bodies in Australia. They identified agricultural commodity councils, rural industry research and development corporations, rural representative bodies, a sample of publicly listed agricultural companies, and government 
and/or semi-government bodies such as area consultative committees (ACCs) regional development boards (RDBs) and catchment management authorities (CMAs) as capturing important leadership roles in rural and regional communities. That so many of the institutions Department of Transport and Regional Services recognize as relevant to regional Australia are associated with agriculture reinforces our earlier point about the dominant role that agriculture is seen to play in regional Australia.

The issue of women's representation on boards (which can be seen as the most senior levels of management) has attracted increasing attention in recent years. The arguments commonly made in favour of women board members, especially nonexecutive ones, are; the increased diversity of opinion in the boardroom; improving the organisation's image with stakeholder groups; their provision of strategic input on women's product/market issues and company direction; improving the constructiveness of board processes and deliberations; their influence on decision making and leadership styles of the organisation; women's capabilities and availability for director positions; insufficient numbers of competent male directors; and providing female role models and mentors to the organisation's female employees (Burgess and Tharenou 2002). It has also been argued that women contribute to better governance, reducing CEO dominance due to their 'power sharing' style (Still 2006), while as non-executive directors they contribute an independent view to the board (Fondas 2000).

All of these arguments seem credible on the surface. However, the current state of representation suggests that they are not sufficient in themselves to improve the situation for women. As Bell and Berry (2007) point out, despite decades of diversity research, and anti-discrimination legislation, women remain significantly 
underrepresented in key organisational positions. In the Australian context, the EOWA Census has shown us that 'Australia now lags all other reporting countries in percentages of companies with at least one woman Executive Manager’ (Equal Opportunity for Women in the Workplace Agency 2008, 10).

Table 3 summarizes women's representation in these rural and regional entities. Women's representation is highest in those organizations formed to promote greater selfreliance in local communities, with women making up; 28 percent of the members and 20 percent of the CEOs of Area Consultative Committees (government sponsored regional development organization); 25 per cent of Regional Development Board (state and community-based economic development organization) members and 16 per cent of Regional Development Board CEOs; and 26 per cent of members and 15 per cent of CEOs of CMAs.

Insert Table 3 here

It seems from these data there are some leadership roles where women are seen to be more welcome. In particular, the more local the focus of the organization, the more accessible the roles have been for women. The Area Consultative Committees and Regional Development Boards, with their stated roles of 'facilitating' interaction, are apparently more open to women (Sheridan et al. 2006), as such activity is consistent with the linking of the public and private - work traditionally seen to be the domain of women (Midgley 2006). In contrast, those leadership roles more closely associated with 'men’s business', and with a less 'local' focus - the agricultural councils, the Research \& 
Development corporations, rural representative bodies and publicly listed agricultural companies - significantly fewer women are present as board members or as CEOs. These organisations, with their decision making relevant to shareholders returns (agricultural companies), influence over policy making through representation of interest groups (agricultural commodity councils and rural representative bodies) and control over the allocation of resources for research (research and development corporations), and their domination by men, provide clear examples of the integration of hegemonic masculinity with economic power (Connell and Wood 2005).

Local government plays an essential role in regional communities as 'it is the tier of government with the greatest interest in locality-based development' (Eversole and Martin 2005, 59). It is at this level of government that women have made most inroads, not just in Australia but internationally (Tickell and Peck 1996). Women have increased their representation six-fold since 1980 when they held only five per cent of elected positions (Pini 2005). This trend has been explained as a function of the relatively powerless nature of local government vis a vis the other arms of government, and because it has generally been associated with social-welfarist objectives (Tickell and Peck 1996).

\section{Appointment processes}

From the interviews of women on the Regional Women's Advisory Council (RWAC) an advisory group established to advise the then Deputy Prime Minister - it was clear that for those women who have achieved leadership positions, the processes for their appointment were not transparent. None of the women were able to determine on what basis they had been appointed. One noted: 
I am yet to find very many committees at a federal or state level where it's really transparent as to why your name is suddenly one of the suggested ones on a list.

Another described how she had followed up with the Chair, asking:

How did I get here?' And the reason I asked is because we wanted to see transparent and open processes for appointment of people to boards and we couldn't find one for ours. She said, 'I don’t know and no one’s going to tell you.

These experiences are not unlike those of corporate women who have been appointed to boards, where they report that it is not only their knowledge, but also their contacts, and being a 'known brand', that facilitates entry (Sheridan 2002). From other work in the corporate sector, it was found that significantly more women than men attribute their appointments to their high visibility (Sheridan and Milgate 2003). In practical terms, as one of the RWAC members noted (Sheridan and Haslam McKenzie 2009, 62), this means: 'You have to be noticed by someone. That's the main thing.'

This lack of transparency around appointment processes resonates with data we found in our project on regional development boards (Sheridan et al. 2008). From the interviews and surveys of women and men board members of state based regional development commissions and boards, we concluded that the political nature of the appointment process, and the lack of transparency around how board/commission members are selected, is a significant impediment to why there is not more diversity. The selection criteria are not clearly defined, nor are they explicitly seeking to capture diversity; rather they reinforce existing elites. 
Those people who are already well-connected, with high profiles in their communities, who can commit the time to what are essentially volunteer roles, are those who are most likely to be appointed to the boards/commissions (Sheridan et al. 2008, 16).

Given being 'noticed' is a necessary condition for appointment for board positions in regional organisations, it is not surprising then that women remain under-represented. As noted by McDowell $(1992,60)$ 'the ways in which the concepts of the Western intellectual tradition prioritise the male world view of 'the one' at the expense of the multitudinous 'others' is now almost too well known', nonetheless, as shown by the data presented here, little has changed in leadership circles regarding disproportionate gender representation.

\section{Conclusion}

Contrary to the popular belief that country life is a bucolic, comfortable one, regional areas of Australia are experiencing unprecedented rates of change. Women have challenged the traditional views of women's lives on the land and in regional locations, but little structural change has occurred to enable them equal presence in the formal leadership roles within and outside of their communities. The shifting boundaries of the public and private may have allowed women greater access to the paid workforce, but the gendered assumptions underpinning what counts as 'serious' business remain entrenched.

Being neither from the city or involved with agriculture, women in business in regional Australia have attracted little attention, either from a research or policy making 
perspective. Their invisibility is further exacerbated by their involvement in more service oriented businesses and roles which, while critical to their communities are not, in the dominant masculinist discourse around regional development prevailing in Australia now, recognised as 'real' business. We believe the discursive positioning of regional women in this 'space of betweenness' is in fact a triple jeopardy, rendering them invisible as candidates for many of the formal leadership roles in their communities.

Clearly there is a need for research to further interrogate the multiple dimensions to the 'space of betweenness' that women aspiring to formal leadership roles in regional communities experience. While we have focused on Australian research in this paper, we believe this offers a rich site to further understand the broader field of regional governance.

\section{Acknowledgments}




\section{References}

Alston, Margaret. 1995. Women on the Land: the Hidden Heart of Rural Australia.

Kensington: UNSW Press.

1996. Backs to the wall: Rural women make formidable activists. In Social

Change in Australia, ed. G. Lawrence, K. Lyons, K and G. Momtaz.

Rockhampton: Rural Social and Economic Research Centre.

1998a. Leading women in agriculture. Wagga: Centre for Rural Social Research.

1998b. Farm women and their work: Why is it not recognized? Journal of

Sociology 34, no. 1: 23-34.

1998c. There are just no women out there: How the industry justifies the

exclusion of women from agricultural leadership. Rural Society 8, no. 3: 197-208.

2000. Breaking through the grass ceiling: Women, power and leadership in rural

organizations. London: Harwood Publishers.

Australian Bureau of Statistics. 2007. 2006 Census data: Australia. Canberra: Australian Government Publishing Service.

Australian Government Office for Women \& Minerals Council of Australia. 2007.

Unearthing new resources: Attracting and retaining women in the Australian minerals industry. Canberra: Australian Government Office for Women.

Beer, Andrew. 2000. Regional policy and development in Australia: Running out of solutions? In Land of discontent: The dynamics of change in rural and regional Australia, ed. Bill Pritchard and Phil McManus, page numbers. Sydney:

University of New South Wales Press. 
Beer, Andrew, Alaric Maude, and Bill Pritchard. 2003. Developing Australia's regions:

Theory and practice. Sydney: University of New South Wales Press.

Bell, M, and Daphne Berry. 2007. Viewing diversity through different lenses: Avoiding a few blind spots. Academy of Management Perspectives 21, no. 4: 21-25.

Blake, Megan, and Susan Hanson. 2005. Rethinking innovation: Context and gender. Environment and Planning A 37: 681-701.

Bureau of Transport and Regional Economics. 2006. About Australia's regions, update August 2006. Canberra.

Calas, Marta, and Linda Smircich. 1992. Rewriting gender into organizational theorising: Directions from feminist perspectives? In Rethinking organization, ed. Micahel Reed and Micahel Hughes, page numbers. London: Sage Publications.

Cameron, Jenny, and Julie Katherine Gibson-Graham. 2003. Feminising the economy: Metaphors, strategies, politics. Gender, Place and Culture, 10, 2, 145-157.

Carter, Sara. 2000. Gender and enterprise. In Enterprise and small business: Principles, practice and policy, ed. Sara Carter and Dylan Jones-Evans, page numbers. Harlow: Pearson Education.

Cheshire, Lynda. 2006. Governing rural development: Discourses and practices of selfhelp in Australian rural policy. Aldershot: Ashgate.

Coghill, Lindsay. 1997. Rural Queensland: Challenges for the future. In Internationalising Communities Conference, ed. D. McMillen, page numbers. Toowoomba, University of Southern Queensland.

Connell, Robert, and Julian Wood. 2005. Globalization and business masculinities. Men and Masculinities 7, no. 4, 347-364. 
Conway, Mary Louise, and Alison Sheridan. 2005. Women, small business and regional location. Rural Society 15, no. 1, 55-76.

Department of Transport and Regional Services. 2005. A snapshot of women's representation on selected regional bodies. Women's representation rural and Regional Australia. Canberra: Department of Transport and Regional Services. 2005b. At the table, getting the best people and making the right decisions for regional and rural Australia. Canberra: Department of Transport and Regional Services.

Duerst-Lahti, Georgia, and Rita Mae Kelly. 1995. On governance, leadership, and gender. In Gender power, leadership, and governance, ed.G. Duerst-Lahti and R. Kelly, page numbers. Place: The University of Michigan Press.

Edwards, Paul, and Judy Wajcman. 2005. The politics of working lives. Oxford: Oxford University Press.

Elix, Jane, and Judy Lambert, ed. 1998. Missed opportunities - harnessing the potential of women in Australian agriculture, Volumes 1 and 2. In Rural Industries Research and Development Corporation and Department of Primary Industries and Energy. Canberra.

Equal Opportunity for Women in the Workplace Agency. 2008. Australian census of women in leadership. North Sydney.

Eveline, Joan. 1998. Heavy, dirty and limp stories: Male advantage at work. In Gender and institutions, welfare, work and citizenship, ed. Moira Gatens and Alison Mackinnon, page numbers. Cambridge: Cambridge University Press. 
Eversole, Robyn, and John Martin. 2005. Introduction: Participation and governance in regional economic development. In Participation and governance in regional development, ed. Robyn Eversole and John Martin, page numbers. Oxonbridge: Ashgate.

Fenstermaker, Sarah, and Candice West, ed. 2002. Doing gender, doing difference, inequality, power and institutional change. New York: Routledge.

Fincher, Ruth, and Ruth Panelli. 2001. Making space: Women's urban and rural activism and the Australian state [1]. Gender, Place and Culture 8, no. 2: 129-148.

Fisher, Melanie, P. Hutchison. 1998. Involving rural women makes for powerful partners. In Australian rural women towards 2000, ed. Margaret Alston, page numbers. Wagga Wagga: Centre for Rural Social Research.

Franklin, Margaret Ann, Leonie Short, and Elizabeth Teather, ed. 1994. Country women at the crossroads. Armidale: University of New England Press.

Gibson-Graham, Julie Katherine. 1994. 'Stuffed if I know': Reflections on post-modern feminist social research. Gender, Place and Culture, 1, no. 2: 205-224. 1996. The end of capitalism (as we know it): A feminist critique of political economy. Oxford: Blackwell.

Comment [C3]: Reference 2002. Beyond global vs local: Economic politics outside the binary frame. In Geographies of Power: Placing Scale, ed. Andrew Herod and Melissa Wright, page numbers. Malden: Blackwell Publishing. 2006. The end of capitalism (as we knew it): A feminist critique of poitical economy. Minneapolis: University of Minnesota Press. 
Glover, Judith, and Gill Kirton. 2006. Women, employment and organizations. London: Routledge.

Grant, Julie, and Al Rainnie. 2005. The hidden role of gender exclusion in regional development agencies. In Participation and governance in regional development, ed. Robyn Eversole and John Martin, page numbers. Oxenbridge: Ashgate.

Halpin, Darren. 2004. Transitions between formations and organisations: An historical perspective on the political representation of Australian farmers. The Australian Journal of Politics and History 50, no. 4: 469-491.

Hanson, Susan, and Geraldine Pratt. 1988. Reconceptualising the links between home and work in urban geography. Economic Geography 64, no. 4: 299-321.

Haslam McKenzie, Fiona. 1998. Farm women and the 'F' word. In Australian rural women towards 2000, ed. Margaret Alston, page numbers. Wagga Wagga: Centre for Rural Social Research.

1999. Boys' clubs: Discriminatory voting practices in agricultural peak industry organizations. International Review of Women and Leadership, Special Issue.

Haslam McKenzie, Fiona, and Linley Lord. 2002. The status of women in rural, regional and remote Australia. In Commonwealth Office of the Status of Women Year Book 2001, ed. Commonwealth Office of the Status of Women, page numbers. Canberra: ACT, Department of Prime Minister and Cabinet.

Houghton, Kim, and Peter Strong. 2004. Women in business in rural and remote Australia: Growing regional economies. Canberra: Rural Industries Research and Development Corporation. 
Katz, Cindi. 1994. Playing the field: Questions of fieldwork in geography. The Professional Geographer 46, no. 1: 73-80.

Lawson, Victoria. 2007. Geographies of Care and Responsibility. Annals of the Association of American Geographers 97, no. 1: 1-11.

Liepins, Ruth. 1998. Fields of action: Australian women's agricultural activism in the 1990s. Rural Sociology 63, no. 1: 128-156. 2000. Exploring rurality through 'community' discourse, practices and spaces shaping Australian and New Zealand rural 'communities'. Journal of Rural Studies 16: 325-341.

Lovering, John. 2001. The coming regional crisis (and how to avoid it). Regional Studies 34, no. 4: 349-354.

Martin, Deborah, Susan Hanson, and Danielle Fontaine. 2007. What counts as activism? The role of individuals in creating change? Women's Studies Quarterly 35, no. 3/4: 78-94.

Martin, Patricia Yancey. 1996. Gendering and evaluating dynamics: Men, masculinities and management. In Men as managers, managers as men, critical perspectives on men, masculinities and managements, ed. David Collinson and Jeff Hearn, page numbers. London: Sage Publications.

McDowell, Linda. 1992. Multiple voices: Speaking from inside and outside 'the project'. Antipodes, 24, no. 1: 56-72. 1993. Space, place and gender relations: Part 1. Feminist empiricism and the geography of social relations. Progress in Human Geography 17, no. 2: 157-179. 
2004. Work, workfare, work/life balance and an ethic of care. Progress in Human Geography 28, no. 2: 145-163.

Midgley, Jane. 2006. Gendered economies: Transferring private gender roles into the public realm through rural community development. Journal of Rural Studies 22: 217-231.

Nast, Heidi. 1994. Women in the field: Critical feminist methodologies and theoretical perspectives. Professional Geographer 46, no. 1: 54-66.

Oberhauser, Ann, Jennifer Mandel, and Holly Hapke. 2004. Gendered livelihoods in diverse global contexts: An introduction. Gender, Place and Culture 11, no. 2: 205-208.

Oberhauser, Ann, and Amy Pratt. 2004. Women’s collective economic strategies and political transformation in rural South Africa. Gender, Place and Culture 11, no. 2: $229-256$.

OECD. 2003. Women's entrepreneurship: Issues and policies. Working party on small and medium-size enterprises and entrepreneurship. Paris: OECD.

Office of the Director of Equal Opportunity in Public Employment. 1998. Women in the lead. Sydney: NSW Government Publication.

Pike, Andy, Andres Rodriguez-Pose, and John Tomanay. 2007. What kind of local and regional development and for whom? Regional Studies 41, no. 9: 1253-1269.

Pini, Barbara. 2003. Sheep, shadows and silly saints: Constructing women in agricultural leadership. Rural Society 13, no. 2: 193-207. 2005a. The third sex: Women leaders in Australian agriculture. Gender, Work and Organization 12, no. 1: 73-88. 
. 2005c. Tradition and change: Gender relations and Australian local government. Australian and New Zealand Academy of Management. Canberra: ANZAM. . 2006. A critique of new regional governance: The case of gender in a rural Australian setting. Journal of Rural Studies 22, no. 4: 396-408.

Pini, Barbara, Kerry Brown, and Chris Ryan. 2004. Women only networks as a strategy for change? A case study from local government. Women in Management Review 19, no. 6: 286-292.

Pini, Barbara, Kerry Brown, and Lynne Simpson. 2003. Evaluating 'Australian women in agriculture' 1992-2002. Australian Journal of Public Administration 62, no. 1: 2431.

Powell, Gary, and Laura Graves. 2003. Women and men in management, 3rd edition. Thousand Oaks: Sage Publications.

Rees, Teresa. 2000. The learning region? Integrating gender equality into regional economic development. Policy and Politics 28, no. 2: 179-191.

Rindfleish, Jennifer, and Alison Sheridan. 2003. No change from within: Senior women managers' response to gendered organizational structures. Women in Management Review 18, no. 6: 299-310.

Sheridan, Alison. 2002. What you know and who you know: 'Successful' women's views on accessing board positions. Career Development International 7, no. 4: 203210.

Sheridan, Alison, Fiona Haslam-McKenzie, Leonie Still, and Mary Louise Conway. 2008. Regional boards: Understanding the impact of gender diversity on board performance. Final Report. Armidale: University of New England. 
Sheridan, Alison, and Gina Milgate. 2003. 'She says, he says': Women's and men's views of the composition of boards. Women in Management Review 18, no. 3: 147-154.

Sheridan, Alison, and Gina Milgate. 2005. Accessing board positions: A comparison of female and male board members' views. Corporate Governance: An International Review 13, no. 6: 847-855.

Sheridan, Alison, Barbara Pini, and Mary Louise Conway. 2006. Modestly staffed and modestly resourced: An exploratory critique of women’s entry to rural and regional governance. Rural Society 16, no. 4: 271-282.

Shortall, Sally. 2002. Gendered agricultural and rural restructuring: A case study of Northern Ireland. Sociologia Ruralis 42, no. 2: 160-176.

Sinclair, Amanda. 2005. Doing leadership differently. Melbourne: Melbourne University Press.

Smith, Darren. 2007. Editorial: The changing faces of rural populations: '(Re)fixing the gaze' or 'eyes wide shut'? Journal of Rural Studies 23, no. 4: page numbers.

Staeheli, Lynn. 1994. A discussion of 'women in the field': The politics of feminist fieldwork. The Professional Geographer 46, no. 1: 96-102. . 2003. Women and the work of the community. Environment and Planning A 35, no. 4: 815-831.

Staeheli, Lynn, and Eleonore Kofman. 2004. Mapping gender, making politics: Towards feminist political geography. In Mapping women, making politics: Feminist perspectives on political geography, ed. Lynn Staeheli, Eleonore Kofman and Linda Peake, page numbers. London: Routledge. 
Still, Leonie. 2004. Women in management in Australia. In Women in Management Worldwide: Progress and Prospects, ed. M. Davidson and R. Burke, page numbers. Ashgate: Aldershot.

. 2006. Where are the women in leadership in Australia? Women in Management Review 21, no. 3: 180-194.

Still, Leonie, and Viti Simmons. 2005. Enterprising women in rural, regional and remote Australia. SEAANZ Armidale: SEAANZ.

Teather, Elizabeth. 1995. Origins of the new farm women's movement in Canada, New Zealand and Australia. Rural Society 5, no. 4: page numbers.

Tickell, Adam, and Jamie Peck. 1996. The return of the Manchester men: Men's words and men's deeds in the remaking of the local state. Transactions of the Institute of British Geographers 21, no. 4: 635-648.

Trauger, Amy. 2004. 'Because they can do the work': Women farmers in sustainable agriculture in Pennsylvania, USA. Gender, Place and Culture, 11, no. 2: 289-307. Wajcman, Judy. 1999. Managing like a man. Sydney: Allen \& Unwin.

Wilkinson, Jane, and Margaret Alston. 1999. Let's walk the talk inside the department. Wagga Wagga: Centre for Rural Social Research,Charles Sturt University. 
Table 1: Women's employment in regional Australia

\begin{tabular}{|l|l|l|l|l|l|l|}
\hline & \multicolumn{3}{|l|}{ Females } & \multicolumn{3}{l|}{ Males } \\
& $\begin{array}{l}\text { Major } \\
\text { urban }\end{array}$ & $\begin{array}{l}\text { Med } \\
\text { township }\end{array}$ & $\begin{array}{l}\text { Small } \\
\text { township }\end{array}$ & Rural & Australia & Australia \\
\hline $\begin{array}{l}\text { Agriculture, forestry } \\
\text { and fishing }\end{array}$ & 0.5 & 1.2 & 2.7 & 15.0 & 2.5 & 4.8 \\
\hline Goods producing & 11.0 & 9.4 & 11.5 & 24.3 & 12.5 & 35.2 \\
industries & & & & & & \\
\hline Service Industries & 89.0 & 90.6 & 88.5 & 75.7 & 87.5 & 64.8 \\
\hline All industries & 100.0 & 100.0 & 100.0 & 100.0 & 100.0 & 100.0 \\
\hline
\end{tabular}

Source: Department of Transport and Regional Services (2005b) 
Table 2: Employed women in rural and regional Australia, by occupation

\begin{tabular}{|l|l|}
\hline Occupational group & $\begin{array}{l}\text { Proportion of employed women } \\
\text { in each occupation }\end{array}$ \\
\hline Managers and administrators & 7.6 \\
\hline Professionals & 18.2 \\
\hline Associate Professionals & 11.8 \\
\hline Tradespersons and related workers & 3.6 \\
\hline Advanced clerical and service workers & 6.5 \\
\hline Intermediate clerical, sales and service & 24.4 \\
workers & \\
\hline Intermediate production and transport & 2.4 \\
\hline workers & \\
\hline Elementary clerical, sales and service & 14.1 \\
\hline workers & \\
\hline Labourers and related workers & 9.5 \\
\hline Inadequately described & 0.6 \\
\hline Not stated & 1.4 \\
\hline Soure: Austaian Bureau of Statstcs & \\
\hline
\end{tabular}

Source: Australian Bureau of Statistics (2007) 
Table 3: Women's share of board positions in rural and regional Australia

\begin{tabular}{|l|l|l|}
\hline Rural and regional bodies & \% women members & \% women CEOs \\
\hline Agricultural commodity & 9 & 0 \\
\hline Research and development & 16 & 0 \\
corporations & & \\
\hline Rural representative bodies & 13 & 2 \\
\hline Agricultural companies & 7 & 0 \\
\hline Regional development & 25 & 16 \\
boards & & 20 \\
\hline Area consultative & 28 & \\
committees & & 15 \\
\hline Catchment management & 26 & \\
authorities & & \\
\hline
\end{tabular}

Source: Department of Transport and Regional Services (2005)

\section{Notes}

${ }^{1}$ Australian Standard Geographical Classifications (ASGC) (see AGPS, 2001, Catalogue No. 1216.0).

2 We acknowledge that where we draw on others' work in the rest of this paper, quoting their words directly, there may be some inconsistencies between their language and ours. 